\title{
INVENTING ABORIGINES
}

\author{
Bob Reece
}

This article is in two parts. The first is by way of a preamble which looks at Aborigines as a category and the way in which that category has been 'assimilated' into a national historiography. The second part is a specific discussion of Aboriginal-European interaction in the early European occupation of the Perth area. It seeks to question the general application of the dispossession-resistance interpretation of Aboriginal responses and to suggest that, at least in this case, accommodation with Europeans was something for which Aborigines strove. It also suggests that the European presence, particularly during the early period of settlement, was an important new variable in the politics of Aboriginal inter-group relations.

In an important sense, Aborigines are both an invention and a product of European colonisation of Australia. It seems an obvious point to make, but when the British first came to Australia in the late eighteenth century there were no Aborigines (with a capital 'A'). Instead, there were possibly as many as 600 identifiable groups or peoples possessing pretty much the same technology and social system but differentiated in their own eyes by very specific kin, geographical, linguistic and other associations. Partly for the sake of convenience, partly out of ignorance of these differences, Europeans referred to them collectively as 'Indians', 'aboriginal natives', 'Australians', 'black natives', 'blacks', 'blackfellows' and finally, 'Aborigines' or 'Aboriginals'. So the aboriginal peoples or indigenes of Australia became 'the Australian Aborigines' or simply 'the Aborigines'. Some use was made of local group names in the nineteenth century after the period of frontier conflict had ended and the remnants had become a source of antiquarian curiosity and philanthropic concern. But by the early twentieth century few of the names had survived in the Australian popular consciousness and today it would be hard to find any layman who could volunteer more than one or two names. ${ }^{1}$

As with the American Indians, the handful of Aborigines who are known historical figures largely owe their status to bloody conflict and the obstruction of European settlement. In Western Australia, Yagan and Pigeon are now being seen by some historians as resistance

Bob Reece is at present Professor of Australian Studies at University College, Dublin, on leave from the History division of the School of Social Inquiry at Murdoch University, Western Australia. He is author of Aborigines and colonists: Aborigines and colonial society in New South Wales in the 1830s and 1840s (1974) and was, with Diane Barwick, co-editor of the first few volumes of Aboriginal History.

1 When $I$ teach Aboriginal history I ask my students to name half a dozen North American Indian tribes and leaders and then to do the same for the Aborigines. The response is predictable, although things may be changing now that Aborigines and Aboriginal issues such as land claims are more prominent in the media and some Aboriginal history is finding its way into school texts. When I was a child at school in the Riverina in the 1940 s a steady diet of Western films and comics meant that I could rattle off the names of a few dozen Indian tribes and warriors. The only Aborigines I encountered were on cards in packets of Weetbix. 
figures, ${ }^{2}$ although this rather distorts or over-simplifies their historical roles. Aboriginal groups who have become well known in recent times - the Gurindji and the Pitjantjatjara for example - also owe their fame to their obstruction of European-Australian economic interests.

So the Aborigines were invented as a convenient, if fictitious, entity or category, but the whole process of dispossession, depopulation, acculturation, segregation and institutionalisation (including legal definition of who was an Aborigine) over the next hundred years was to fulfil the linguistic prediction by manufacturing Aborigines as a relatively homogeneous social group - possessing a diverse cultural heritage but a fairly uniform historical experience at the hands of Europeans. While they were seen collectively as the indigenous people, however, they were not accorded any legal constitutional personality appropriate to that status. Indeed, that question has still not been settled, but the emergence of Aborigines as an identifiable political minority in Australia since the 1930s is now putting pressure on the lawyers to re-consider the usefulness of conventional European concepts such as 'settlement' and 'conquest'.

Historians have been as much the perpetrators of categorisation as other Australians. Together with anthropologists, we have given the term 'Aborigines' further legitimacy even going to the extent of suggesting that, in the nineteenth century, Aborigines constituted a national political entity.

Having invented and manufactured Aborigines, we are now producing their past as part of a national historiography. Although doubt has been cast on the validity and usefulness of national historiography itself, and while regional and thematic approaches have become more common, there still seems to be a naive need to generalise about the Australian experience' - something which has become all the more pressing with the Bicentenary. Part of this is a need to generalise about 'the Aboriginal experience', a concept which is similarly problematical.

The reasons for the marginality of Aborigines in Australian historical writing during the first half of this century have been widely canvassed. ${ }^{4}$ But although Aborigines have returned to the national stage, the rendering of their history has been subject to distortions of the kind that make all attempts at national historiography suspect. The concept of 'resistance' has made it possible to generalise about 'the Aboriginal experience' at a time when Aboriginal issues have been a matter of wide political concern and this has not been without its beneficial effects. However, we need to test not only the general validity of the 'resistance' interpretation against the historical evidence, but to question the attempts to produce a kind of national historiography for the aboriginal peoples of Australia. This does not mean, of course, that European Australians cannot or should not write Aboriginal history, ${ }_{5}^{5}$ but that they should be more cautious in writing about an entity which has been fictional until recent times and of using concepts which have the effect of giving credibility to that fiction. They should also be careful not to present themselves as writing history for Aborigines as surrogate

Pedersen 1984:7-15.

3 Hookey 1984:1-18.

4 Hartwig 1972:9-24; Reynolds 1972:471-7; Reece 1979:253-7.

5 See Identity 4(5), 1981:7-8. 
Aboriginal nationalists. ${ }^{6}$ This would be presumptuous as well as silly.

In the last decade the old orthodoxy that European occupation of the Australian continent was essentially peaceful (that the Aborigines 'simply faded away') has been replaced by a new orthodoxy. We are now told that Aboriginal reaction to the European presence was characterised by 'resistance', indeed, that it is maintained today by Aboriginal activists and groups seeking land rights. The broken black figures in our city parks should not be seen as 'alcoholic derelicts' but as 'patriots' passively resisting the European lifestyle and its accompanying ethic.

Evidence of massacres and individual killings across Australia has led Henry Reynolds to ask rhetorically if we should 'make room ... on our memorials, cenotaphs, boards of honour and even in the pantheon of national heroes ...' for Aborigines who 'fell defending their homelands'? Although it may not have been the intention, the dispossession-resistance 'model' or interpretation of Aboriginal-European interaction is now a powerful academic orthodoxy which is being incorporated in tertiary as well as secondary level school texts. Perhaps the only serious academic challenge to it has been Noel Butlin's effort to demonstrate on the basis of statistical extrapolations that epidemic diseases and Aboriginal internecine strife were more important than European violence in the dramatic depopulation of south-eastern Aborigines in the nineteenth century. ${ }^{8}$ Butlin has enlarged the demographic dimensions of the problem by suggesting a much larger original population than has been hitherto believed. At the same time, however, he has reduced the moral dimensions of the problem with his emphasis on disease and the consequent reduction of resource competition between Aborigines and Europeans. A proper critique of his methodology and his conclusions has yet to be made, although Diane Barwick seriously questioned his use of nineteenth-century sources. ${ }^{9}$

The concept of 'resistance' raises almost as many problems as it solves. Loaded with connotations of the anti-colonial movements of the period since the Second World War, particularly the struggles of the Vietnamese against the French and the Americans, 'resistance' and 'resistance fighter' have become part of the anti-colonial polemic. Brought into the arena of Aboriginal-European conflict in Australia commencing in the late eighteenth century, they can produce some gross distortions. To take one example, the task of Barry York and Fergus Robinson's The black resistance, published in 1977, has been described by Humphrey McQueen as establishing that violent struggle by Aborigines against foreign invasion was an ongoing and continent-wide response. This they achieved by choosing to interpret every example of Aboriginal attack on Europeans and their property as 'resistance' or 'warfare'. More recently, Ian Roberts ${ }^{10}$ and Lorna Lippmann ${ }^{11}$ have attempted to trace a genealogy of resistance from 1788 to Noonkanbah.

6 See e.g. Christie's introduction to his Aborigines in colonial Victoria 1835-1886, 1979.

7 Reynolds 1982:201.

8 Butlin 1983.

9 Barwick 1984.

10 Roberts 1981.

11 Lippmann 1982. 
From the Aboriginal side, conflict with Europeans arose from misunderstandings, European notions of property and exclusive use of land, European sacrilege of sacred sites and objects, competition over women, revenge, and a host of other factors which we probably do not yet understand. In some situations there does seem to have been a reflexive opposition to the European presence from the outset. In others it seems to have developed after years of contact. As Reynolds himself says, 'the evidence ... suggests that Aborigines attacked and killed Europeans for a variety of reasons'. ${ }^{12}$ Precisely, and it is wrong to subsume all these reasons under the rubric of 'resistance' and create the impression that it was all of a piece.

It can be seen that 'resistance' has served a useful purpose in overthrowing the notion that the Aborigines simply 'faded away'. Henry Reynolds, Noel Loos and others have performed an important service in quantifying the conflict (particularly in Queensland) and revealing Aborigines as far from passive victims of European onslaught. In so doing, however, they have created the impression that 'resistance' of some kind was the typical Aboriginal response to the European presence from one end of the continent to the other.

In their enthusiasm to document the bloodiness of the process of colonisation, Reynolds and others have not been so interested in documenting and highlighting that other major characteristic of Aboriginal-European interaction: accommodation. Perhaps this in itself is a reflection of the character of Aboriginal political action during the decade when Reynolds was preparing The other side of the frontier: a period which was typified by sometimes violent physical confrontations between Aborigines and police and by the belligerent rhetoric of the Black Power movement in Australia. Reynolds himself was quite explicit about the political purpose of his book, emphasising that it was not conceived, researched, or written in a mood of detached scholarship'. ${ }^{13}$ By contrast, we are now going through a period during which Aboriginal political action is relatively low-key. As Hugh Stretton has reminded us, what we seek to find in history has a great deal to do with our perception of the world around us. ${ }^{14}$ We must be sensitive to the problems of 'presentism', of writing history which merely extends current political and ideological preoccupations into the past. Reynolds provided some evidence of Aboriginal efforts to reach agreement with the newcomers, but this was overshadowed by his greater interest in conflict and its causes. In fact, the Aboriginal desire for accommodation was more marked than Reynolds acknowledges.

Rather than depending on the dispossession-resistance model which seems to be the basis for Reynolds' analysis, we should look at the accommodation model which has been used in the historiography of other parts of the British Empire, notably the African colonies. In his analysis of nineteenth-century West Africa, for example, Ronald Robinson described the way in which the European presence became an important variable in the indigenous political systems of that area. ${ }^{15}$ Alliances with Europeans sometimes allowed indigenous élites to maintain their position longer than they might otherwise have done. Instead of a system of 'divide and rule' in which the colonialists called the shots, there seems to have been one of 'ally and rule' in which the interests of certain indigenous groups were promoted at the

12 Reynolds 1982:85-6.

13 Reynolds 1982:1.

14 Address to the Australian Historical Association conference, Adelaide, August 1986.

15 Robinson 1978:141-63. 
expense of the colonising power.

Although the aboriginal peoples of Australia did not possess the hierarchical social systems which characterised West Africa, they had their own mode of political interrelations. Alliances were made with neighbouring groups through trade and exogamous marriage and, although kin relationships did not prevent conflict, they probably limited it to manageable dimensions. What is clear is that groups who lay beyond the perimeters of kin, trade, and linguistic ties were perceived as being rather like enemy aliens. There are boundless examples in contact history of the vilification of distant groups of Aborigines as 'cannibals' and so on. George Grey told a story about the people north of Perth who counselled him in 1838 'indiscriminately to shoot everybody I saw' on his planned journey to the north-west coast. ${ }^{16}$ Miago (Migo), a Swan River man who accompanied J.L. Stokes to that area on board the Beagle a year earlier, freely expressed his desire to kill some of the northern men he met with and seize their women. 17

The problem for the historian is that these political relationships between Aboriginal groups and the ties which underpinned them are difficult to reconstruct from the surviving evidence. For example, there is as yet no reliable account of the groups who inhabited the Swan coastal plain: the descriptions made by Lyon, ${ }^{18}$ Armstrong ${ }^{19}$ and others during the early 1830 s are confused and contradictory. Perhaps they were so intertwined by kinship links over hundreds of generations that they were always shifting in composition in spite of fairly clear territorial divisions. However, it is possible to identify four main groups: 'Yalagonga's people' (Yallagonga), occupying the left bank of the Swan in the immediate area of Perth; 'Monday's people', occupying the right bank of the Swan from Guildford down to Heirrison Island; Midgegooroo's people' south of the Swan; and 'the Murray River people'. For the sake of convenience, the first three groups can also be referred to collectively as the 'Perth Aborigines', who numbered about three hundred in 1829. According to Armstrong, Yalagonga's group tended to ally itself on the basis of kin relations with another group north of Perth, while Midgegooroo's group was allied with Monday's group. ${ }^{20}$

There is no evidence that the Aborigines of the Swan coastal plain generally opposed the presence of the first European settlers. According to Armstrong, when the Europeans made it clear that they were taking up permanent residence 'some of them became hostilely disposed to the settlers - but others cared or thought little about it, until they began to find the kangaroo and other game getting alarmingly scarce'. ${ }^{21}$ They told Armstrong that 'on the whole, they have treated the settlers well; for that, if any native strangers had attempted to settle among them in the same way, they would have done all in their power to destroy them'. ${ }^{22}$ What they did, however, was to contest the Europeans' exercise of exclusive ownership and control of land and its resources. This took the form of 'theft' of flour and other

16 Grey $1841, \mathrm{I}: 293$.

17 Stokes $1846,1: 58,74-5$. Migo is a variant spelling for the same name, see Tilbrook 1986.

18 Lyon, Perth Gazette, 1833.

19 Armstrong, Perth Gazette, 1835.

20 Armstrong, Perth Gazette, 1835.

21 Armstrong, Perth Gazette, 1835.

22 Armstrong, Perth Gazette, 1835. 


\section{INVENTING ABORIGINES}

goods from houses and storehouses, 'raids' on crops and gardens and 'at tacks' on livestock. If the Europeans would not agree to share the fruits of the land, it was necessary to take them by force. As marsupials and yams disappeared and access to land and water was denied by proprietorial Europeans, Aboriginal needs became more marked and their methods more desperate. When Europeans intervened to protect their property, they often killed Aborigines or seriously injured them. Sometimes they were attacked by Aborigines, although the mortality was heavily to the cost of the latter. Nor was this only due to the superiority of firearms over spears. Many Europeans were entirely ruthless in their defence of their own or their masters' property and there were no real disincentives to the taking of Aboriginal lives.

The shooting of Yagan and his brother Hegan in July 1833, following the deaths earlier that year of his other brother, Domjum, and their father, Midgegooroo, seems to have persuaded the Perth Aborigines that an agreement was needed with the Europeans to prevent further loss of life. Since the beginning of settlement in 1829, at least sixteen Aborigines had been killed and twice that many wounded in the Perth area ${ }^{23}$ representing a major loss to an adult population as yet largely unaffected by European-introduced diseases. According to Miago and Monday, after the killing of one of the European boys who had shot Yagan, the Aborigines had been anxious that the Europeans would kill more of them if they took more European lives in revenge and had immediately gone off and killed one or two members of Monday's group. ${ }^{24}$

The Perth Gazette inferred from this that they are afraid of retaliating upon us; and suspect their numbers, by being so much reduced, will be rendered unequal to cope with the neighbouring tribes. 25

Armstrong believed that killings of this kind were due to the need to appease the spirits of the dead, 'and not from any motives of policy to keep the numbers of their neighbours on a level with their own, and to preserve the "balance of power". 26 However, the death of Yagan had apparently resulted in closer links between his group south of the Swan and Yalagonga's people in Perth itself, who had suffered the greatest loss of numbers.

Miago and Monday, evidently delegated by the Aboriginal groups on both sides of the lower Swan, waited on Lieutenant-Governor F.C. Irwin in September 1833, complaining that shooting was too severe a punishment for theft and that it was wrong to endanger the lives of other Aborigines for the actions of one individual. For example, in the incident involving Domjum, Yagan's brother, at Fremantle in April 1833 two of his companions had been severely wounded. Miago and Monday wanted what the Perth Gazette called an 'amicable treaty' or an 'amnesty' to prevent any further shootings and retaliatory spearings. ${ }^{27}$ They maintained their right to retaliate against any individual who injured them, but were concerned about the cost in lives that European retaliation usually meant. They were also bitterly opposed to the government's idea of conciliating the more distant Aboriginal groups, stressing that the latter were still in possession of their hunting grounds. According to the Gazette 'they argued that as we had deprived them of their game, they ought to be the

\footnotetext{
23 Green 1979:70-94.

24 Perth Gazette, 7 September 1833.

25 Perth Gazette, 7 September 1833.

26 Armstrong, Perth Gazette, 12 November 1836.

27 Perth Gazette, 7 September 1833.
} 
objects of our consideration'. ${ }^{28}$ At the same time, they expressed the wish that Europeans would go into the bush with them and 'boo' (shoot) or help spear any members of another group that they encountered. Irwin pressed for a friendly meeting of all 'tribes', but he also acknowledged the Perth Aborigines' loss of sustenance as a result of European settlement and offered what amounted to compensation:

His Honour ... proposed, that if they were at any time distressed for food, from casual circumstances, their kangaroo or other resources failing them, they might come into the town, and they would be supplied with provisions; they described that we had taken possession of their hunting and fishing grounds - and that our dogs had driven the kangaroo 'far away' They privately told Mr. Armstrong ... that they found mutton was a very good substitute. ${ }^{29}$

A year later, Governor James Stirling decided to set up a 'Native Institution' near the 39th Regiment barracks at the foot of Mount Eliza to the west of the town, a traditional camping place of Yalagonga's people. And although its official rationale was to train Aborigines in fishing and agricultural techniques which would render them self-sufficient once more, it in fact served until 1838 as a ration depot which was well patronised. The Aborigines of the Perth area had largely abandoned their traditional seasonal movements and were effectively 'attached' to the settlement in the same way that had happened in Sydney almost fifty years earlier.

The constant presence of Aborigines in the town of Perth was met with mixed feelings by the European inhabitants. Nakedness and the carrying of spears aroused protest and when retributive killings of other Aborigines took place in the very streets there were demands that the constables should clear them out altogether. One of these incidents, the ritual killing of a woman by a number of men in St George's Terrace in April 1838, led to the prosecution and conviction for murder of an elder called Eli-a (Helia) who had earlier told Stirling that he would assist the government in preventing incidents of this kind taking place in the public eye. Stirling and his Advocate-General, George Fletcher Moore, were certainly aware of the implications of prosecuting offences inter se and made it clear in their private discussions that it would be unwise and impractical to attempt to enforce British law in this way. This was a significant accommodation from the European side. ${ }^{30}$

The Perth Gazette carried protests and petitions designed to rid the town of these 'nuisances', but it also reminded its readers of the responsibilities they now had towards the Aborigines of the Perth area, whose friendship was the best insurance against attack on the settlement by outlying groups. Fears of this kind had been present from the outset of settlement and an informal alliance was in the interests of both parties. According to the Gazette, all possible protection was to be given to the Perth Aborigines against attack by their traditional enemies, ${ }^{31}$ instances of which were becoming increasingly common as the availability of bread and other items attracted distant groups to the town. Indeed, the tone of official and editorial pronouncements on the Perth Aborigines from 1835 onwards was

28 Perth Gazette, 7 September 1833.

29 Perth Gazette, 7 September 1833.

30 Reece 1988.

31 Perth Gazette, 21 October 1837. 
influenced by the existence of this informal alliance.

Another accommodation was reached in 1835 when the Perth Aborigines seem to have abandoned, albeit reluctantly, what they had earlier seen as their right to exact retribution on Europeans who had killed or injured any of their number. After a series of 'thefts' of flour from a hut at the foot of Mount Eliza, a carpenter called Mackail fatally shot an Aboriginal boy called Gogalee, son of Yalagonga, who had not been involved. Mackail was quickly removed to Fremantle's Round House Gaol, as much for his own safety as anything else, when the Aborigines insisted that he be handed over to them for the traditional punishment of spearing. Delegations representing all the groups in the Perth area visited the prison each day to see if he was still being held and it was only after the most strenuous efforts that they were persuaded to accept flour and blankets and an assurance that Mackail would be banished from the colony. The Gazette attached particular importance to this case, which it saw as threatening the 'good understanding' reached earlier with Yalagonga's people. ${ }^{32}$ The main significance of the Mackail case, however, was that it revealed the inability of the Aborigines to enforce their own system of retributive justice on Europeans and their acceptance that incidents of this kind would be settled by what they called 'the white people's law'.

Apart from the celebrated episode involving Midgegooroo and Yagan, who were outlawed and killed as a result of a chain of events stemming from the 'theft' of flour at Fremantle in April 1833, there were no major conflicts between Aborigines and Europeans in the Perth area during the first decade of settlement and certainly nothing which could be interpreted as Aboriginal attempts to drive away the Europeans. Nevertheless, the uncertain demeanour of Aboriginal groups living outside the perimeter of those known to be more or less friendly created a good deal of anxiety within the small European community. The principal fear was that some of the 'wild blacks' would join forces with the local groups and wipe out the entire settlement.

It was in the area of the Murray River, sixty kilometres south of Perth, that the first major conflict in the colony's history took place in October 1834. Stirling had granted Thomas Peel a huge parcel of land there and Peel was evidently anxious that his possession of it should be brought home to the local Aborigines, who had been attacking stock and had killed one of his servants. In the resulting attack by soldiers under Stirling's orders, now known as the 'Battle of Pinjarra' but in fact a daybreak raid on an unsuspecting Aboriginal camp, at least thirty Aborigines were killed. Stirling made it clear to the remnants of the group that he intended this as a 'lesson', not just to the Murray people but to all Aborigines who attacked European property, and that if they sought revenge for their punishment his troopers would 'destroy every man, worman and child ...,33

Nor did the lesson go unheeded. In March of the following year there was information through Miago that the Murray people were 'anxious to seek a reconciliation'. ${ }^{34}$. According to the Perth Gazette's report of its conversation with him, their proposal was

that an emissary . . . shall wait upon the Governor, confiding in a pledge of security, and shall receive His Excellency's sanction for the introduction of his

32 Perth Gazette, 21 October 1837.

33 Perth Gazette, 1 November 1834 cited in Fletcher 1984:6.

34 Perth Gazette, 28 March 1835. 
tribe, when the whole will be assembled, and will present themselves before him, soliciting his future favour and consideration. For the observance and strict fulfilment of this treaty on the part of the Murray men, we have the guarantee a pledge by-the-by not much required - of the principals of the Swan tribe that they will resent any inf ringement of the solemn compact. ${ }^{35}$

Stirling responded positively to this and authorised Miago to bring the remnants of the group to Perth for the meeting. When it came to the point, however, the Murray people could only be persuaded to go as far as the military barracks at Mandurah,where they were told that the government as well disposed towards them. Rumours, possibly malicious, continued amongst the Perth Aborigines that the Murray people were preparing to avenge Pinjarra and it may be that they were opposed to Miago's diplomacy and any agreement between the government and the Murray people which might weaken their own alliance with the government. What Miago's interest was in all this is not clear, but he can be seen as one of the first of those Aboriginal mediators or 'brokers' described by Michael Howard in his work on the south-west of Western Australia. ${ }^{36}$ Significantly enough, Miago was one of the first Aboriginal constables appointed by Stirling's successor, Governor Hutt, in Perth in 1891.

The picture that emerges from the Swan River situation during the first decade of European occupation is of a number of local Aboriginal groups who were not essentially inimical to the European presence, sometimes seeing it as a form of sanctuary or protection against traditional enemies. They were willing to share their resources, principally land, with the newcomers and when this proved impossible they attempted to make compensatory arrangements which would supply them with food and other items. They attempted at first to bring the Europeans within their own system of justice, including retribution for death or injury, but when this proved too expensive in terms of European response they were then prepared to allow the European system of justice to prevail in the event of offences committed against them. If there is anything that can be helpfully described as 'resistance', it is the series of Aboriginal attempts by means of force to share the food resources which the Europeans had derived from land they never ceased to think of as theirs. The whole process of interaction was characterised by a series of accommodations or adjustments made by people who did not appear to have had an essentially hostile reaction to the European presence but were acutely aware of the Europeans' power to impose their will if need be by force of superior arms: Indeed, they were anxious to use that power as a means of strengthening their position vis- $\grave{b}$-vis outside Aboriginal groups who were feared enemies.

It is difficult to know how 'typical' the Swan River example was and there is no point in merely substituting 'accommodation' for 'resistance' as the key to an understanding of Aboriginal-European relations in Australian history. There is a real need to look more closely at other specific examples of interaction and to be sceptical of simplistic generalisations. Resistance and accommodation can each be seen as forming part of the spectrum of Aboriginal-European relations. There is also a need to be sceptical of the validity of a national Aboriginal historiography, no matter how useful it may be politically to Aborigines and their supporters. There is a need to decolonise Australian historical writing, but let it be done more carefully than good intentions might otherwise dictate.

35 Perth Gazette, 28 March 1835 (emphasis in original).

36 Howard 1981:56-65. 


\section{INVENTING ABORIGINES}

\section{BIBLIOGRAPHY}

Armstrong, F. 'Manners and habits of the Aborigines of Western Australia : . Perth Gazette, 29 October, 5 and 12 November, 1835.

Barwick, Diane. Smallpox observations in Victoria in the nineteenth century. Seminar paper given at the Research School of Social Sciences, Australian National University, 12 April 1984.

Butlin, N.G. Our original aggression. Sydney, 1983.

Christie, M.F. Aborigines in colonial Victoria 1835-86. Sydney, 1979.

Fletcher, Christine. 'The battle for Pinjarra: a revisionist view', in B. Reece and T. Stannage eds, EuropeanAboriginal relations in Western Australia, pp.1-6. Perth, 1984.

Green, Neville, 'Aboriginal and settler conflict in Western Australia, 1826-1852', The Push from the Bush 3, 1979:70-94.

Grey, G. Journals of two expeditions of discovery in north-west and western Australia, during the years 1837,38 and $39 . .2$ vols. London, 1841.

Hartwig, M.C. 'Aborigines and racism: an historical perspective', in F.S. Stevens ed., Racism: the Australian experience, vol.2, pp.9-24. Sydney, 1972.

Hookey, John. 'Settlement and sovereignty', in P. Hanks and B. Keon-Cohen eds, Aborigines and the law: essays in memory of Elizabeth Eggleston, pp.1-18. Sydney, 1984.

Howard, Michael. Aboriginal politics in southwestern Australia. Perth, 1981.

Lippmann, Lorna. Generations of resistance: the Aboriginal struggle for justice. Melbourne, 1981.

Lyon, R.M. 'A glance at the manners, and language of the Aboriginal inhabitants of Western Australia...'. Perth Gazette, 6 and 13 March, 20 April 1833.

Pedersen, Howard. " Pigeon": an Australian Aboriginal rebel', in B. Reece and T. Stannage eds, EuropeanAboriginal relations in Western Australia, pp.7-15. Perth, 1984.

Reece, R.H.W. 'The Aborigines in Australian historiography', in J.A. Moses ed., Historical disciplines and culture in Australasia: an assessment, pp.253-80. St Lucia, Q1d., 1984.

" "Laws of the white people": the frontier of authority in early Western Australia', in B. Hocking ed., International law and Aboriginal human rights, pp.110-36. Sydney, 1988.

Reynolds, Henry. 'Violence, the Aboriginals, and the Australian historian', Meanjin 31 (4), 1972:471-7.

- The other side of the frontier: Aboriginal resistance to the European invasion of Australia. Ringwood, Vic 1982.

Roberts, Jan. From massacres to mining: the colonization of Aboriginal Australia. Blackburn, Vic. 1981.

Robinson, Fergus and B. York. The black resistance: an introduction to the history of the Aborigines' struggle against British colonialism. Melbourne, 1977.

Robinson, Ronald. 'European imperialism and indigenous reactions in British West Africa, 1880-1914', in H.L. Wesseling ed., Expansion and reaction, pp.141-63. Leiden, 1978.

Stokes, J. Lort. Discoveries in Australia . ., , 2 vols. London, 1846.

Tilbrook. Lois. 'A question of access: women, marriage and land ownership in south-western Australia', Aboriginal History 10(2), 1986:99-116.

The Working Party of Aboriginal historians for the Bicentennial History 1788-1988. 'Preparing black history', Identity 4(5), 1981:7-8. 